\title{
A Review: Electrochemical Biosensors for Oral Cancer
}

\author{
Yen-Tzu Lin ${ }^{1,+}{ }^{\dagger}$, Sorour Darvishi ${ }^{2,+}{ }^{\dagger}$, Anant Preet ${ }^{1}$, Tzu-Yen Huang ${ }^{3}$, Sheng-Hsuan Lin ${ }^{4}{ }^{\oplus}$, \\ Hubert H. Girault ${ }^{2}$, Ligang Wang ${ }^{2}$ and Tzu-En Lin ${ }^{1, *(D)}$ \\ 1 Institute of Biomedical Engineering, College of Electrical and Computer Engineering, National Chiao Tung \\ University, Hsinchu 30010, Taiwan; ya8503031119@gmail.com (Y.-T.L.); anantpreet01@gmail.com (A.P.) \\ 2 École Polytechnique Fédérale de Lausanne (EPFL), Valais Wallis, CH-1950 Sion, Switzerland; \\ sorour.darvishi@epfl.ch (S.D.); hubert.girault@epfl.ch (H.H.G.); ligang.wang@epfl.ch (L.W.) \\ 3 Department of Otolaryngology-Head and Neck Surgery, Kaohsiung Medical University Hospital, \\ Kaohsiung Medical University, Kaohsiung 80756, Taiwan; tyhuang.ent@gmail.com \\ 4 Institute of Data Science and Engineering, National Chiao Tung University, Hsinchu 30010, Taiwan; \\ shenglin@nctu.edu.tw \\ * Correspondence: telin@nctu.edu.tw \\ + The first and second author contributed equally to the work.
}

Received: 1 June 2020; Accepted: 8 July 2020; Published: 13 July 2020

Abstract: Oral cancer poses a serious threat worldwide owing to its soaring case-fatality rate and its metastatic characteristics of spreading to the other parts of the body. Despite the recent breakthroughs in biomedical sciences, the detection of oral cancer at an early stage is still challenging. Conventional diagnosis in clinics and optical techniques to detect oral cancer in the initial stages are quite complicated as well as not completely accurate. To enhance the survival rate of oral cancer patients, it is important to investigate the novel methodologies that can provide faster, simpler, non-invasive, and yet ultraprecise detection of the onset of oral cancer. In this review, we demonstrate the promising aspects of an electrochemical biosensor as an ideal tool for oral cancer detection. We discuss the cutting-edge methodologies utilizing various electrochemical biosensors targeting the different kinds of biomarkers. In particular, we emphasize on electrochemical biosensors working at the molecular levels, which can be classified into mainly three types: DNA biosensors, RNA biosensors and protein biosensors according to the types of the analytes. Furthermore, we focus on the significant electrochemical methods including cyclic voltammetry (CV), differential pulse voltammetry (DPV) and electrochemical impedance spectroscopy (EIS) to analyze the oral cancer biomarkers (such as IL-6, IL-8, CYFRA 21-1, CD 59 and CIP2A) present in body fluids including saliva and serum, using non-invasive manner. Hence, this review provides essential insights into the development of pioneering electrochemical biosensors for the detection of oral cancer at an early stage.

Keywords: electrochemical biosensor; CV; DPV; EIS; oral cancer; interleukin-6 (IL-6); interleukin-8 (IL-8); tumor necrosis factor $\alpha$ (TNF- $\alpha$ ); cytokeratin 19 fragments (CYFRA 21-1); CD 59; cancerous inhibitor of PP2A (CIP2A)

\section{Introduction}

Cancers occurring in the oral cavity are among the most common malignancies in developed countries [1,2]. Each year, about 300,000 new cases of oral cancer are reported and, unfortunately, results in over 140,000 deaths worldwide [3]. In the United States, about 53,000 Americans are diagnosed with oral or oropharyngeal cancer annually, causing over 9750 deaths, killing approximately 1 person every hour [4,5]. Premalignant oral lesions or early-stage cancers are usually asymptomatic, thus usually being ignored at the initial stages, leading to a high mortality rate, especially for male tobacco and alcohol users [6]. It is also reported that oral cancer is associated with betel quid chewing 
in various communities [7-9]. Besides the high fatalities, oral cancer is also a critical factor in reducing productivity in developing countries from early deaths [3,10]. Conventional methods for the diagnosis of oral cancer and premalignant lesions (e.g., leukoplakia and erythroplakia) mainly rely on visual inspection and biopsy. Oral cancer includes several types of carcinoma, most often refers to as squamous cell carcinoma (SCC) [11]. To investigate the biomarkers responsible for these malignancies, and to diagnose oral cancer in the early stages, biosensor advancement is vital [12].

At present, the initial diagnosis of oral cancer is made by performing an invasive method such as tissue biopsy of the affected region, followed by further assessment using non-invasive medical imaging techniques including computed tomography (CT), magnetic resonance imaging (MRI) or positron emission tomography (PET) scans which are quite expensive and complicated [1,13]. In comparison to conventional inspection methods, electrochemical biosensors provided with relatively high sensitivity, enhanced specificity, and non-invasive detection methods for biomolecules [14,15]. Furthermore, these biosensors won't be much affected by challenges like optical interference or sample turbidity [16]. In this review, we discuss the cutting-edge methodologies utilizing various electrochemical biosensors for detecting oral cancer. In general, they can be classified into mainly three types: DNA biosensors, RNA biosensors and protein biosensors based on their sensing targets. Furthermore, we focus on the significant electrochemical methods including cyclic voltammetry $(\mathrm{CV})$, differential pulse voltammetry (DPV) and electrochemical impedance spectroscopy (EIS) to analyze the oral cancer biomarkers (Figure 1). Biomarkers can be detected in the body fluids such as serum and saliva, as shown in Table 1. In the following sections, we summarize the fundamental methodologies that are essential for electrochemical biosensors development for monitoring the behavior of numerous biomarkers in oral cancer.
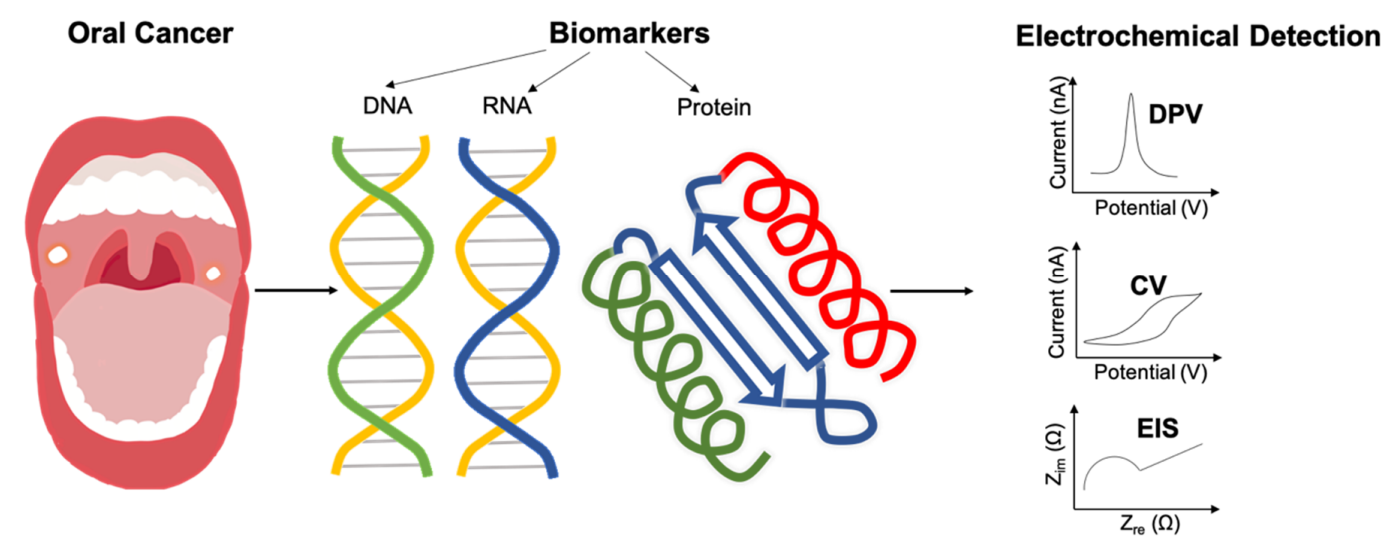

Figure 1. Schematic illustration of an oral cancer-detecting process by using electrochemical biosensors. Abbreviations: Differential pulse voltammetry (DPV); Cyclic voltammetry (CV); Electrochemical impedance spectroscopy (EIS).

\section{Electrochemical Methodologies for Biosensing}

\subsection{DNA Biosensor}

In most cases, target DNA collected from human body fluid needed to be centrifuged and purified. DNA biosensors detects the target DNA by modifying the working electrode with complementary sequences $[17,18]$. Usually, the gold electrode, screen-printed carbon electrode and glassy carbon electrode are utilized as the working electrode for the electrochemical set-up, while indium tin oxide (ITO) can also be used [19]. Ma et al. developed a ratiometric electrochemical DNA sensor for direct analysis of target DNA in artificial saliva specimens, by integrating the exonuclease III-assisted amplification with dual-signal ratiometric output mode [20]. Thus, it enables the detection of a lower concentration of biomarkers. Firstly, oral cancer overexpressed 1 (ORAOV1) DNA is hybridized with a ferrocene-labeled hairpin probe $\left(\mathrm{F}_{\mathrm{c}}\right.$-Probe), then separated by exonuclease III releasing the target DNA, 
which is followed by the next amplification cycle. The amount of the residual $F_{c}$ probe is quantified by using an electrochemical method. The residual $\mathrm{F}_{\mathrm{c}}$ probe is hybridized with the methylene blue-labeled hairpin probe (MB-labeled probe), then a modified MB-labeled probe is fixed on the gold electrode and used as a working electrode. Once the $F_{c}$ probe combines with the MB-labeled probe, the electric current would decrease. Thus, the more the ORAOV1 DNA presents in saliva, the more $\mathrm{F}_{\mathrm{c}}$ probe would be consumed, and the higher current would be detected (as shown in Figure 2a). Chen et al. also developed a DNA biosensor to detect ORAOV1 [21]. They modified signal probes that contain target recognition sequences, nicking the endonuclease recognition sequence and G-rich sequence on a bare gold electrode, forming a cycle after a hybridized signal probe cleaved by the nicking enzyme. Finally, the addition of hemin to bind with a G-rich sequence that is located on signal probes and catalyzed the $\mathrm{H}_{2} \mathrm{O}_{2}$-mediated oxidation of $3,3^{\prime}, 5,5^{\prime}$ tetramethylbenzidine (TMB) to acquire current signal. However, the performance of DNA biosensors is not always very satisfactory along with the metal electrode because of DNA denaturation. To overcome this challenge, Wei et al. introduced a biocompatible DNA dendrimer system, a short nanoscale of DNA modified on the working electrode surface. They adopted a 16-Array electrochemical chip with three electrodes to detect multiple biomarkers simultaneously as shown in Figure 2b [22]. Eventually, the signal level got higher, and the amount of denatured species get lower.

(a)

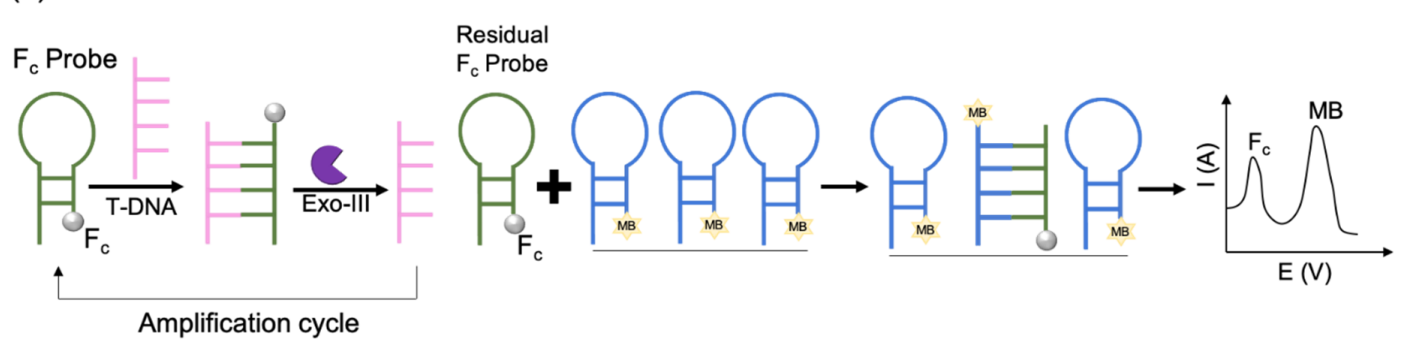

(b)

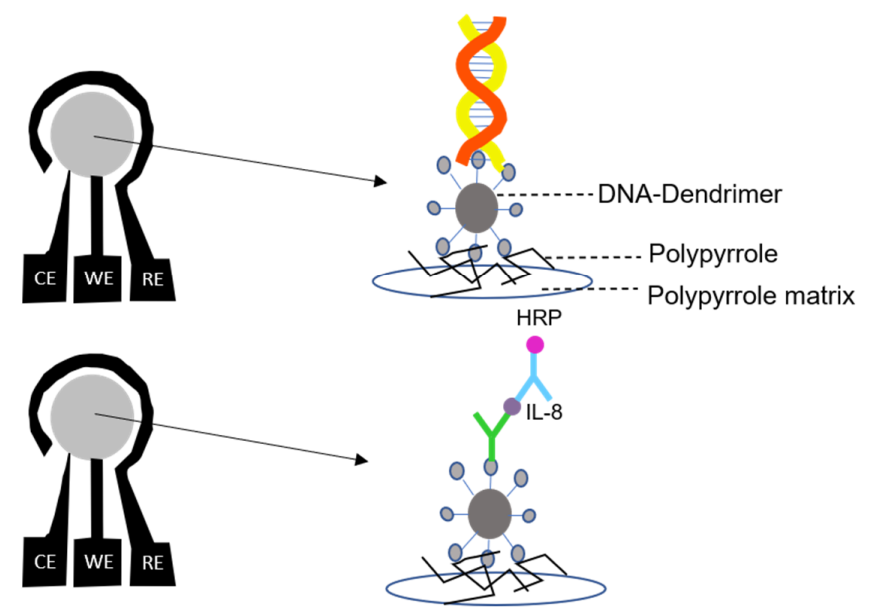

Figure 2. (a) Schematic illustration of the Exo-III involved in the DNA target amplification cycle and the signal readout of electrochemical DNA biosensor. (b) The three-electrode configuration on the electrochemical chip and illustration of biomolecules immobilize on DNA dendrimer. Abbreviations: Ferrocene-labeled hairpin probe (Fc); Exonuclease III (Exo-III); Methylene blue (MB); Counter electrode (CE); Working electrode (WE); Reference electrode (RE); Horseradish peroxidase (HRP); Interleukin 8 (IL-8).

\subsection{RNA Biosensor}

RNA biosensors are often combined with magnetic beads utilizing the junction strategy to ensure the biosensors achieve better sensitivity and a higher distinction ability. Wang et al. reported the modification of capture probes on magnetic beads. As depicted in Figure 3a, a magnetic bead is capable 
of binding numerous capture probes along with the target and the signal probe, getting absorbed on the surface of the electrically magnetic-controllable working electrode on the addition of a voltage on the electric coil $[10,11]$. Hence, the electrochemical current signal increased because horseradish peroxidase (HRP) catalyzed the $\mathrm{H}_{2} \mathrm{O}_{2}$-mediated oxidation of TMB after immersing the working electrode in TMB- $\mathrm{H}_{2} \mathrm{O}_{2}$ solution. As illustrated in Figure $3 \mathrm{~b}$, the magnetic beads were captured on the dual screen-printed carbon electrode (SPdCE) as working electrodes so that target mRNA and target interleukin-8 (IL-8) could be detected simultaneously in the same samples. Furthermore, hydroquinone (HQ) can be used as a redox mediator in the $\mathrm{H}_{2} \mathrm{O}_{2}$ solution to monitor the current generation and analysis of each target's concentration in artificial saliva.

(a) Oral cancer related microRNA

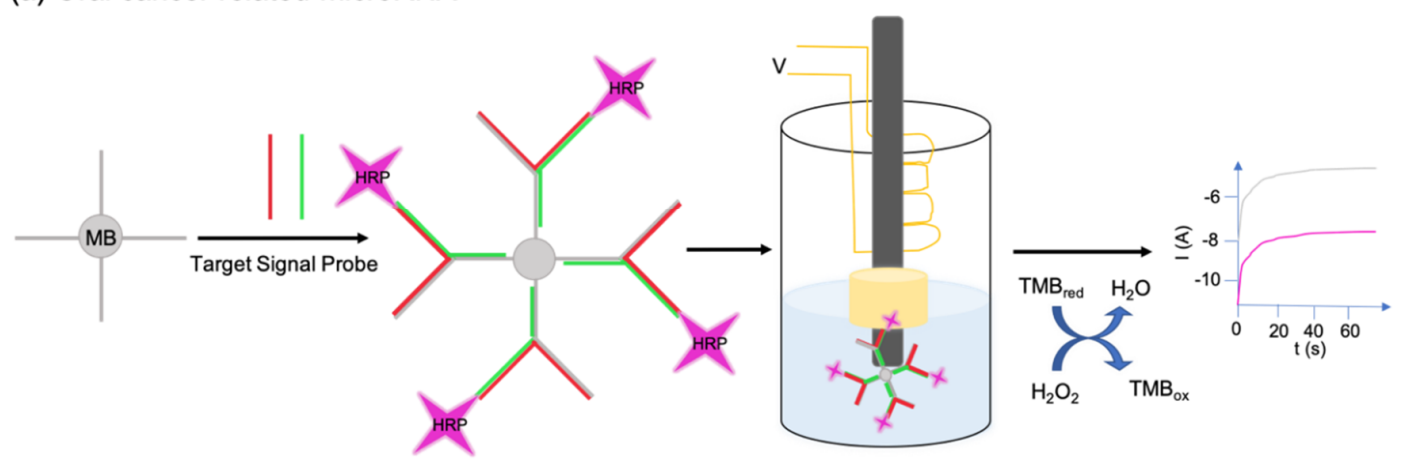

(b) IL-8 mRNA
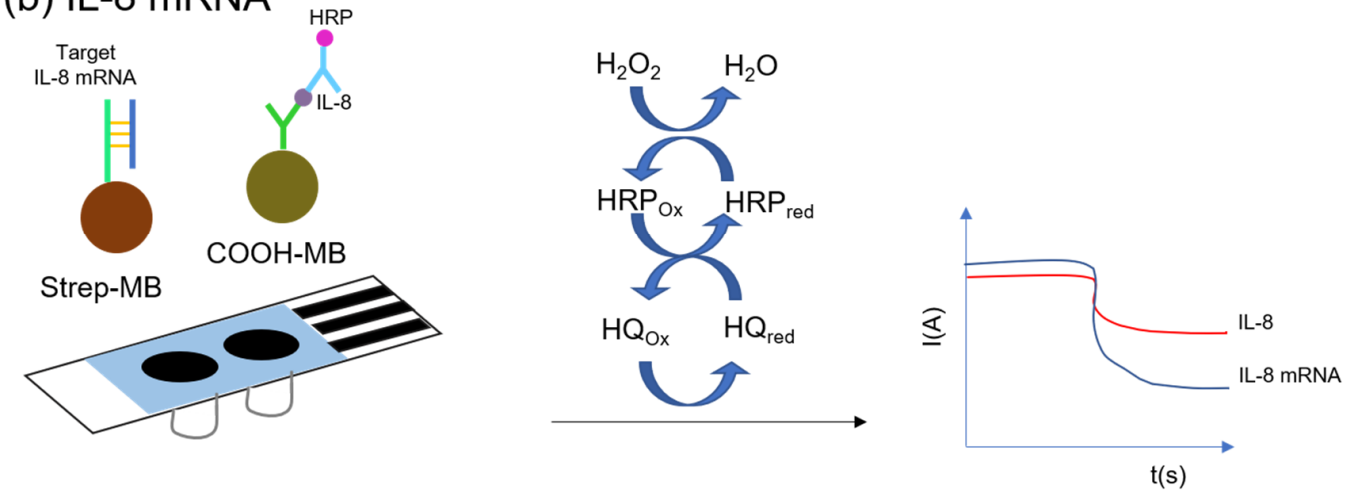

Figure 3. (a) The principle of the magnetic-controllable electrochemical RNA biosensor. (b) The modified MBs on SPdCE for the simultaneous determination of IL-8 protein and IL-8 mRNA. Abbreviations: Magnetic bead (MB); Horseradish peroxidase (HRP); 3,3' ,5,5' Tetramethylbenzidine (TMB); Interleukin 8 (IL-8); Streptavidin-modified magnetic bead (Strep-MB); Carboxylic acid-modified magnetic bead (HOOC-MB); Hydroquinone (HQ).

\subsection{Protein Biosensor}

Electrochemical biosensors for measuring protein cancer biomarkers offer a sensitive, quick, and cheap diagnosis framework for point of care (POC) and clinical analysis [23]. In these biosensors, the surface of the electrodes usually is modified with receptors such as antibodies or aptamers. Consequently, the explicit protein analytes are measured with the assistance of quantifiable and electroactive species generated from themselves or a signal transducer that has been added into the solution. Immunosensors are highly selective since the interactions between an antibody and an antigen act like a lock and key binding mechanism [24]. Protein biomarkers for cancer detection are broadly applicable for measuring elements that are considered as indicators of abnormal biological processes, disease processes, or responses to therapeutic intermediation [19,25]. Theses biomarkers usually can be extracted from serum, tissue, or saliva, and their expression levels can be expressive 
of disease states. Several tumor markers can be easily found in saliva which makes the salivary sample in a high level of interest for the non-invasive detection of oral cancer [26,27]. Recent studies have shown both cell-free mRNAs and proteins in saliva display diagnostic values for oral cancer, as previously mentioned [28]. One of the pioneers for the multiplexed electrochemical sensors for the determination of salivary biomarkers for oral cancer detection was reported by Wei et al. as mentioned in Section 2.1 the detection of a certain protein [22]. Their results showed that the multiplex detection of both interleukin-8 (IL-8) mRNA and protein allows an accurate diagnosis for oral cancer detection. In another study, human saliva samples used for the detection of protein IL-8 and IL-8 mRNA by the development of electrochemical magnetobiosensors [29]. In this research, highly sensitive and selective methodologies were reported. Moreover, the detection limits are $0.21 \mathrm{nM}$ for IL-8 mRNA and $72.4 \mathrm{pg}$ $\mathrm{mL}^{-1}$ for IL-8 protein in undiluted saliva samples. The development of reliable immunosensor for POC application for early detection of certain proteins is of interest, especially for an ultra-low concentrated sample without interference from the variety of other non-analyte proteins in serum and saliva [29-34]. The gold standard method for clinical detection of biomarkers is enzyme-linked immunosorbent assay (ELISA) [31]. ELISA has the limits of detection (LOD) of $1-3 \mathrm{pg} \mathrm{mL}^{-1}$ for many protein analytes [19,30]. However, ELISA is limited by costly test kits and equipment, long time of measuring, and difficulties in multiplexing. Consequently, ELISA is not the first choice for the application of POC diagnostics.

Compared with traditional biosensors, aptamer-based biosensors characterized label-free, high sensitivity for electrochemical detection [35,36]. Qureshi et al. developed a capacitive aptasensor to monitor human epidermal growth factor receptor 2 (HER2) protein which was an overexpressed biomarker in many cancers including ovarian, lung, gastric, and oral cancers [37]. Anti-HER2 aptamers (ssDNA) are immobilized on a gold microelectrode surface. Then, dilute human serum was spiked with various concentrations of HER2. Ultimately, the relationship between capacitance and HER2 concentration was measured. The results showed that a dynamic range was between 0.2 and $2 \mathrm{ng}$ $\mathrm{mL}^{-1}$, without adding any redox-chemicals [35]. In another studies, aptamers were utilized for the detection of IL-6 protein. For instance, Kumar et al. reported a nano-aptamer sensor to detect IL-6 in biofluids like sweat using EIS. In this study, aptamers against IL-6 were immobilized on gold nanoparticles deposited on the gold working electrode for capturing the analyte [38]. The detection limit was estimated as $0.02 \mathrm{pg} \mathrm{mL}^{-1}$. Furthermore, the aptasensors had $90 \%$ of the original signal of impedance response after 2 weeks which indicates the high stability of the sensor. Another example is that Tertis et al. developed an IL-6 aptasesnsor based on a glassy carbon electrode modified by p-aminobenzoic acid, p-aminothiophenol and gold nanoparticles [39]. The aptasensor showed the detection limit of $1.6 \mathrm{pg} \mathrm{mL} \mathrm{mL}^{-1}$ and high selectivity in the blood sample.

Another type of protein sensor is based on immunoassays. In a typical sandwich immunoassay, a recognized element, such as primary antibody, is immobilized on an electrode surface to capture the specific analyte. In the next step, secondary antibody conjugated with an enzyme, for instance, horseradish peroxidase (HRP), is added into the solution for binding the antigen (the analyte). HRP can convert its substrate to electrochemically active species, so that the chemical signal can be converted to electrochemical signal through this step [29,40-43]. For instance, Heineman' group pioneered in enzyme-linked electrochemical detection of the analyte using sandwich immunoassays [32]. In this research, two main procedures are being utilized for multiplex electrochemical protein identification. First, the primary antibody was used for binding the analytes, and then the secondary antibodies were attached to nanoparticles. Second, electrodes were utilized by immobilizing with various antibodies and for measuring the electrochemical signals. In addition to their research, the improvement of delicate and precise electrochemical biosensing frameworks relies on bioreceptor, redox mediators and transducer networks. In recent years, nanomaterials are popular, and they are widely applied in the biosensor field owing to their high surface-to-volume ratio. New carbon or metal nanomaterials have been innovated, such as graphene and its derivatives, with special properties including high electron transfer rate, high biocompatibility, and thus many studies combine nanomaterials with immunosensors [29,33,44-46]. Nanostructure based immunosensors increase electrode surface area, 
which can provide 10-fold or more antibody coverage compared to flat surfaces, leading to enhanced sensitivity of up to 1000-fold and lower limit of detection [34,47-49].

In addition to oral cancer biosensors, electrochemical biosensors systems for the detection of cancer biomarkers using similar principles have been developed for several types of cancer including lung cancer [47,50], melanoma [51-53] breast cancer [36,54,55] and prostate cancer [56]. Electrochemical signal amplification in these biosensors could be achieved by estimating electroactive chemical responses released or consumed from an enzyme, for example HRP [20,54,57]. Other electrochemical detection methods relied on special nanoparticles labeled on antibodies. This complex could be further dissolved to gain detectable electroactive species [25,32,34,58-61]. Protein sensors for targeting various important biomarkers were listed in the following sections.

Table 1. Biomarkers that have been used for oral cancer electrochemical biosensors and the experimental conditions.

\begin{tabular}{|c|c|c|c|c|c|}
\hline Biomarker & Sample & $\begin{array}{l}\text { Electrochemical } \\
\text { Method }\end{array}$ & Detection Limits & $\begin{array}{l}\text { The Levels of The Biomarker in } \\
\text { Normal Case and Cancer Patient }\end{array}$ & References \\
\hline Amylase & $\begin{array}{c}\text { Samples spiked in } \\
\text { potassium ferrocyanide }\end{array}$ & Cyclic voltammetry & $1.57 \mathrm{pg} \mathrm{mL}^{-1}$ & 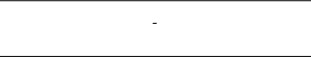 & [23] \\
\hline $\begin{array}{c}\text { IL-8 protein, IL-1 } \beta \\
\text { protein and IL- } 8 \mathrm{mRNA}\end{array}$ & Samples spiked in buffer & cyclic square-waveform & $\begin{array}{l}\text { Protein:100-200 } \mathrm{fg} \mathrm{mL}^{-1} \\
\text { mRNA IL-8:10 aM }\end{array}$ & $\begin{array}{l}\text { IL-8 protein, OSCC patient: } 720 \mathrm{pg} \\
\mathrm{mL}^{-1} \text {; Normal: } 250 \mathrm{pg} \mathrm{mL} \mathrm{mL}^{-1} \\
\mathrm{IL}-8 \text { mRNA, patient: } 16 \mathrm{fM} ; \\
\text { Normal:2 } \mathrm{fM}\end{array}$ & [24] \\
\hline Interleukin-6 (IL-6) & HNSCC cell lines & Amperometry & $2.5 \times 10^{-14} \mathrm{M}$ & $\begin{array}{l}\text { IL-6 protein, HNSCC patient: more } \\
\text { than } 20 \mathrm{pg} \mathrm{mL}^{-1} ; \text { Normal: }^{-} \\
\text {less than } 6 \mathrm{pg} \mathrm{mL}^{-1}\end{array}$ & [25] \\
\hline microRNA & Artificial saliva & $\begin{array}{l}\text { Cyclic voltammetry } \\
\text { Chronoamperometry }\end{array}$ & $2.2 \times 10^{-19} \mathrm{M}$ & - & [30] \\
\hline $\begin{array}{l}\text { IL-6 protein, } \\
\text { IL-8 protein }\end{array}$ & Serum & Amperometry & IL-6:5 fg mL ${ }^{-1}$, IL-8:7 fg mL & $\begin{array}{l}\text { IL-6 protein, } \mathrm{HNSCC} \text { patient: more } \\
\text { than } 20 \text { pgmL }{ }^{-1} \text {; Normal: } \\
\text { less than } 6 \mathrm{pg} \mathrm{ml}^{-1} \\
\text { IL-8 protein, patient: } 720 \mathrm{pg} \mathrm{mL}^{-1} \text {; } \\
\text { Normal: } 250 \mathrm{pg} \mathrm{mL}^{-1}\end{array}$ & [31] \\
\hline $\begin{array}{c}\text { Oral Cancer } \\
\text { Overexpressed } 1\end{array}$ & Human saliva & $\begin{array}{l}\text { Differential pulse } \\
\text { voltammetry }\end{array}$ & $0.35 \mathrm{pM}$ & - & [19] \\
\hline IL- 8 protein, TNF- $\alpha$ & Artificial saliva & I-V Curve & $100 \mathrm{fg} \mathrm{mL}^{-1}$ & $\begin{array}{l}\text { IL-8 protein, patient: } 720 \mathrm{pg} \mathrm{mL}^{-1} \\
\text { Normal: } 250 \mathrm{pg} \mathrm{mL}^{-1}\end{array}$ & [32] \\
\hline $\begin{array}{l}\text { IL-8 mRNA } \\
\text { IL-8 protein }\end{array}$ & Human saliva & Amperometry & $\begin{array}{l}\text { IL-8 mRNA: } 0.21 \mathrm{nM} \\
\text { IL-8: } 72.4 \text { pg mL }\end{array}$ & $\begin{array}{c}\text { IL-8 mRNA, patient: } 16 \mathrm{fM} \text {; } \\
\text { Normal: } 2 \mathrm{fM} \\
\text { IL-8 protein, patient: } 720 \mathrm{pg} \mathrm{mL}^{-1} \text {; } \\
\text { Normal: } 250 \mathrm{pg} \mathrm{mL}^{-1}\end{array}$ & [29] \\
\hline CYFRA-21-1 & $\begin{array}{l}\text { Samples spiked in PBS } \\
\text { buffer }\end{array}$ & $\begin{array}{l}\text { Cyclic voltammetry } \\
\text { Electrochemical } \\
\text { impedance spectroscopy }\end{array}$ & $\begin{array}{l}0.21 \mathrm{ng} \mathrm{mL}^{-1} \\
\text { (calculated) }\end{array}$ & $\begin{array}{l}\text { CYFRA-21-1 protein, normal: } 3.8 \mathrm{ng} \\
\mathrm{mL}^{-1} ; \text { patient:17.46 } \pm 1.46 \mathrm{ng} \mathrm{mL}^{-1}\end{array}$ & [34] \\
\hline CYFRA-21-1 & $\begin{array}{c}\text { Samples spiked in PBS } \\
\text { buffer }\end{array}$ & $\begin{array}{l}\text { Cyclic voltammetry } \\
\text { Differential pulse } \\
\text { voltammetry }\end{array}$ & $\begin{array}{l}0.122 \mathrm{ng} \mathrm{mL}^{-1} \\
\text { (calculated) }\end{array}$ & $\begin{array}{l}\text { CYFRA-21-1 protein, normal: } 3.8 \mathrm{ng} \\
\mathrm{mL}^{-1} ; \text { Patient:17.46 } \pm 1.46 \mathrm{ng} \mathrm{mL}^{-1}\end{array}$ & [33] \\
\hline CYFRA-21-1 & Artificial Saliva & $\begin{array}{l}\text { Differential pulse } \\
\text { voltammetry }\end{array}$ & $0.001 \mathrm{ng} \mathrm{mL}^{-1}$ & $\begin{array}{l}\text { CYFRA-21-1 protein, normal: } 3.8 \mathrm{ng} \\
\mathrm{mL}^{-1} \text {; Patient:17.46 } \pm 1.46 \mathrm{ng} \mathrm{mL}^{-1}\end{array}$ & [47] \\
\hline CD59 & Human saliva & $\begin{array}{l}\text { Cyclic voltammetry } \\
\text { Electrochemical } \\
\text { impedance spectroscopy }\end{array}$ & $\begin{array}{l}\text { Treated Saliva: } 0.84 \pm 0.04 \mathrm{fg} \mathrm{mL}^{-1} \\
\text { Raw saliva: } 1.46 \pm 0.05 \mathrm{fg} \mathrm{mL}^{-1}\end{array}$ & - & [48] \\
\hline IL-8 protein & Human saliva & $\begin{array}{l}\text { Cyclic voltammetry } \\
\text { Differential pulse } \\
\text { voltammetry }\end{array}$ & $72.73 \pm 0.18 \mathrm{pg} \mathrm{mL}^{-1}$ (calculated) & $\begin{array}{l}\text { IL-8 protein, patient: } 720 \mathrm{pg} \mathrm{mL}^{-1} \text {; } \\
\text { normal: } 250 \mathrm{pg} \mathrm{mL}^{-1}\end{array}$ & [49] \\
\hline $\begin{array}{l}\text { Oral Cancer } \\
\text { Overexpressed } 1\end{array}$ & Artificial saliva & $\begin{array}{c}\text { Alternating current } \\
\text { voltammetric } \\
\text { Electrochemical } \\
\text { impedance spectroscopy } \\
\end{array}$ & $12.8 \mathrm{fM}$ & - & [20] \\
\hline CIP2A & Human saliva & $\begin{array}{l}\text { Cyclic voltammetry } \\
\text { Electrochemical } \\
\text { impedance spectroscopy }\end{array}$ & $0.24 \mathrm{pg} \mathrm{mL}^{-1}$ & - & [57] \\
\hline CYFRA-21-1 & Human saliva & $\begin{array}{c}\text { Differential pulse } \\
\text { voltammetry } \\
\text { Electrochemical } \\
\text { impedance spectroscopy } \\
\end{array}$ & $0.625 \mathrm{pg} \mathrm{mL}^{-1}$ & $\begin{array}{l}\text { CYFRA-21-1 protein, normal: } 3.8 \mathrm{ng} \\
\mathrm{mL}^{-1} ; \text { Patients: } 17.46 \pm 1.46 \mathrm{ng} \\
\mathrm{mL}^{-1}\end{array}$ & [54] \\
\hline IL-8 protein & Human serum and saliva & $\begin{array}{l}\text { Cyclic voltammetry } \\
\text { Electrochemical } \\
\text { impedance spectroscopy } \\
\text { Single Frequency } \\
\text { Impedance }\end{array}$ & $3.3 \mathrm{fg} \mathrm{mL} L^{-1}$ & $\begin{array}{l}\text { IL-8 protein, patient: } 720 \mathrm{pg} \mathrm{mL}^{-1} \text {; } \\
\text { Normal: } 250 \mathrm{pg} \mathrm{mL}^{-1}\end{array}$ & [58] \\
\hline IL-8 protein & Human saliva & $\begin{array}{l}\text { Cyclic voltammetry } \\
\text { Differential pulse } \\
\text { voltammetry }\end{array}$ & $\begin{array}{l}51.53 \pm 0.43 \mathrm{pg} \mathrm{mL}^{-1} \\
\quad \text { (calculated) }\end{array}$ & $\begin{array}{l}\text { IL-8 protein, patient: } 720 \mathrm{pg} \mathrm{mL}^{-1} \\
\text { Normal: } 250 \mathrm{pg} \mathrm{mL}\end{array}$ & [59] \\
\hline
\end{tabular}




\subsubsection{Proteins Biosensors Targeting IL-6 and IL-8}

IL-6 and IL-8 are cellular proteins that are particularly relevant to oral squamous cell carcinoma (OSCC) [62-65]. The uncontrolled expression of these cytokines could be a sign of the development of tumor growth and metastasis [65]. Usually, the normal expression levels of these cytokines in keratinocytes are low. IL-6 is an interleukin that behaves as both a pro-inflammatory cytokine and an anti-inflammatory myokine, that is involved in acute-phase reaction, growth regulation and differentiation of cells $[60,66]$. Patients with oral cancer have 20 to $1000 \mathrm{pg} \mathrm{mL}^{-1}$ of IL-6 in the serum, while, in healthy individuals, it is $<6 \mathrm{pg} \mathrm{mL}^{-1}$ [17]. IL-8 is a 8-kDa cytokine related to the angiogenic and mitotic processes, and inflammatory response. The serum levels in healthy individuals are lower than $13 \mathrm{pg} \mathrm{mL}^{-1}$ compared with $20-1000 \mathrm{pg} \mathrm{mL}^{-1}$ or more in patients [67]. Figure 4 depicts electrochemical immunosensors based on the detection of biomarkers IL- 6 and IL-8 for targeting oral cancer.

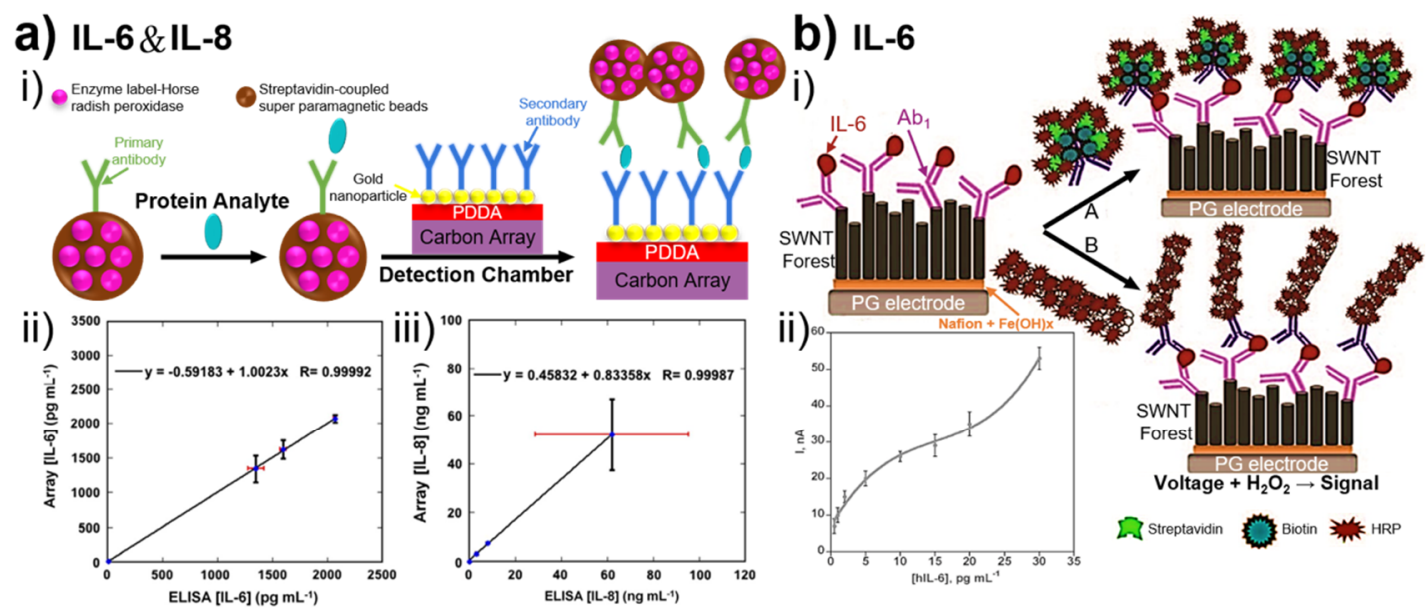

\section{C) IL-8\& TNF a}

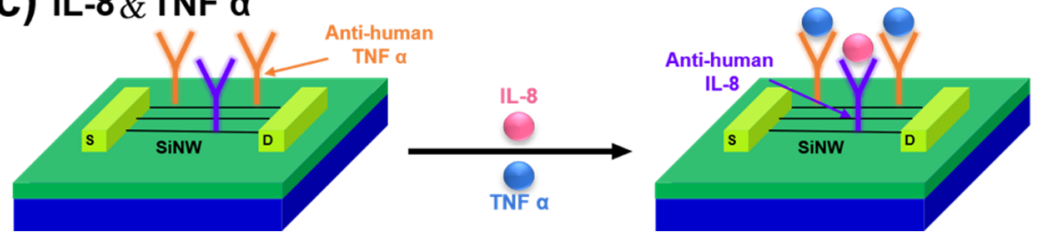

Figure 4. Electrochemical immunosensors based on the detection of biomarkers IL-6 and IL-8 for targeting oral cancer. (a) (i) Conceptual strategy for detection of protein biomarker by micro-fluidic immunoarray. Correlation plots of immunoarray assay results for conditioned media of different cell lines vs. standard ELISA assays for: (ii) IL-6; and (iii) IL-8. (b) (i) Multilabel amperometric immunosensor; and (ii) influence of IL-6 concentration on steady-state current for immunosensor using the bioconjugate. (c) Schematic diagram illustrating SiNW arrays functionalized with two antibodies and two biomarkers. (a) Adapted with permission from ref. [31]. Copyright 2014 Elsevier. (b) Adapted with permission from ref. [25]. Copyright 2010 American Chemical Society. Abbreviations: Poly(diallyldimethylammonium chloride) (PDDA); Interleukin 8 (IL-8); Interleukin 6 (IL-6); Anitbody1 (Ab1); Anitbody2 (Ab2); Single-walled nanotube (SWNT); tumor necrosis factor $\alpha(\mathrm{TNF}-\alpha)$.

Otieno and coworkers developed a sensor array coated with gold nanoparticle-antibody conjugates in a poly(dimethylsiloxane) microchannel [31]. In their investigation, protein analytes were captured on $\mathrm{Ab}_{2}-\mathrm{MP}-\mathrm{HRP}$ bioconjugates from serum or other biological samples. Figure $4 \mathrm{a}(\mathrm{i})$ illustrates the principle for fabricating the sensor. The accuracy of the sensor was verified (Figure $4 \mathrm{a}$ (ii,iii)). The comparison of the obtained results showed good correlations with standard ELISAs. In another study, Malhotra and coworkers reported an ultrasensitive electrochemical immunosensor for targeting IL-6 in head and neck squamous cell carcinoma (HNSCC) cells [25]. The mean concentration of IL-6 in

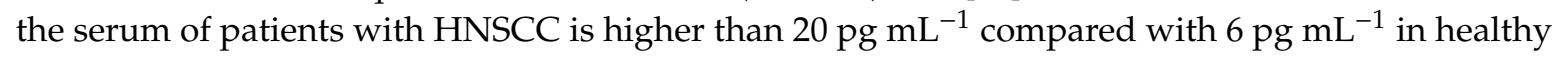


individuals. In this research, the high sensitivity was achieved by nanostructured single-walled nanotube (SWNT) forest platforms. Two strategies were chosen for the multilabel detection in the amperometric immunosensor, as shown in Figure $4 \mathrm{~b}(\mathrm{i})$ : using 14-16 HRPs labeled $\mathrm{Ab}_{2}$; or adding active HRPs modified on carboxylated carbon nanotubes.

In another study, Zhang et al. reported a field-effect transistor (FET) sensor for the detection of two biomarkers of OCSS in saliva samples, IL- 8 and TNF- $\alpha$, by using a silicon nanowire (SiNW) (Figure 4c) [32]. The detection of biomarkers in real saliva sample is very tricky since it contains complex components. They overcame this problem by functionalizing with two different antibodies immobilized on the surface of the electrode for capturing IL-8 and tumor necrosis factor $\alpha$ (TNF- $\alpha$ ) and avoiding the cross-reactivity of biomarkers carefully (Figure 4c).

In recent years, two-dimensional (2D) graphene-based materials are widely used in biosensors because of their unique properties including high mechanical stability, biocompatibility and high rate of electron transfer $[33,68,69]$. The advantages of graphene-based biosensors can be roughly concluded into two points. First, graphene oxide (GO) contains certain functional groups that can be easily covalently bonded to biomolecules. Second, the structural defects of GO, reduced graphene oxide (rGO) and graphene-based quantum dots (GQDs) can be used to immobilize the biomolecules onto their surfaces. Graphene-based sensors are successfully used for the incorporation of nanoparticles and/or hydrogel for electrochemical detection of various analytes including glucose [70,71], DNA, cholesterol oxidase, and NADH, etc. [72]. Verma and coworkers fabricated immunosensor based on the gold nanoparticles-reduced graphene oxide (AuNPs-rGO) composites for non-invasive IL-8 detection in the saliva sample [49]. The reported immunosensor has shown fast detection (9 min) of IL-8 and offers high sensitivity with an experimental linear dynamic range of $500 \mathrm{fg} \mathrm{mL}^{-1}$ to $4 \mathrm{ng} \mathrm{mL}^{-1}$ and a detection limit of $72.73 \pm 0.18 \mathrm{pg} \mathrm{mL}^{-1}$. The high sensitivity and rapid detection were due to the high rate of electron transfer through the thin film of AuNPs-rGO nanocomposites.

\subsubsection{Protein Biosensors Targeting Other Biomarkers}

Besides IL-6 and IL-8, some other biomarkers have also been employed for electrochemical detection of oral cancer. Kumar and coworkers reported a non-invasive, label-free immunosensor based on nanostructured hafnium oxide (hafnia) deposited onto indium tin oxide (ITO) coated glass for detection of CYFRA-21-1 in human saliva [34]. CYFRA-21-1 is a remarkable tumor marker for squamous cell carcinoma (SCC). However, the clinical value of CYFRA-21-1 in OSCC has not been validated [73]. Figure $5 \mathrm{a}(\mathrm{i})$ shows the steps of the fabrication of BSA/anti-CYFRA-21-1/APTES/ $/ \mathrm{nHfO}_{2} / \mathrm{ITO}$ immunosensor. The BSA/anti-CYFRA-21-1/APTES/ $\mathrm{nHfO}_{2} / \mathrm{ITO}$ electrode responded according to the concentration of CYFRA-21-1 (2-18 $\left.\mathrm{ng} \mathrm{mL}^{-1}\right)$, shown in Figure 5 a(ii). In this biosensor, it was found that the CV peak current gradually decreased linearly with increased concentration of CYFRA-21-1. The decreased current was due to the formation of electrically insulating antigen-antibody complex which prevents the electron transfer through redox mediator. The current responses recorded for the real samples (Figure 5a(iii)) were matched with the current signals obtained for standard samples of the same concentration. This result showed an excellent correlation between the current from the real sample.

The first application of vertically aligned carbon nanotube array (VANTA) interdigitated electrodes (IDEs) for electrochemical detection of CIP2A was reported by Ding and coworkers [54]. IDEs worked as electrochemical transducers, consisting of several electrodes which were electrically connected together [74,75]. CIP2A is a cancer biomarker for a variety of human cancers including lung, breast and gastric cancers. However, CIP2A is extensively expressed in OSCC cell lines, and malignant human oral epithelial tissues [76]. The scheme in Figure $5 \mathrm{~b}(\mathrm{i})$ represents the steps of the fabrication of immunosensor. The dimensions of VANTA IDEs are shown in Figure 5b(ii). Moreover, the highly porous VANTA structures were observed with field-effect scanning electron microscopy (FESEM) (Figure 5b(iii,iv)) in two magnifications. The label-free immunosensor for detecting CIP2A showed a wide linear sensing range (1-100 $\mathrm{pg} \mathrm{mL}^{-1}$ ) with a good detection limit of $0.24 \mathrm{pg} \mathrm{mL}^{-1}$ in saliva. 
Furthermore, the electrochemical immunosensor showed higher sensitivity than the corresponding CIP2A ELISA test.

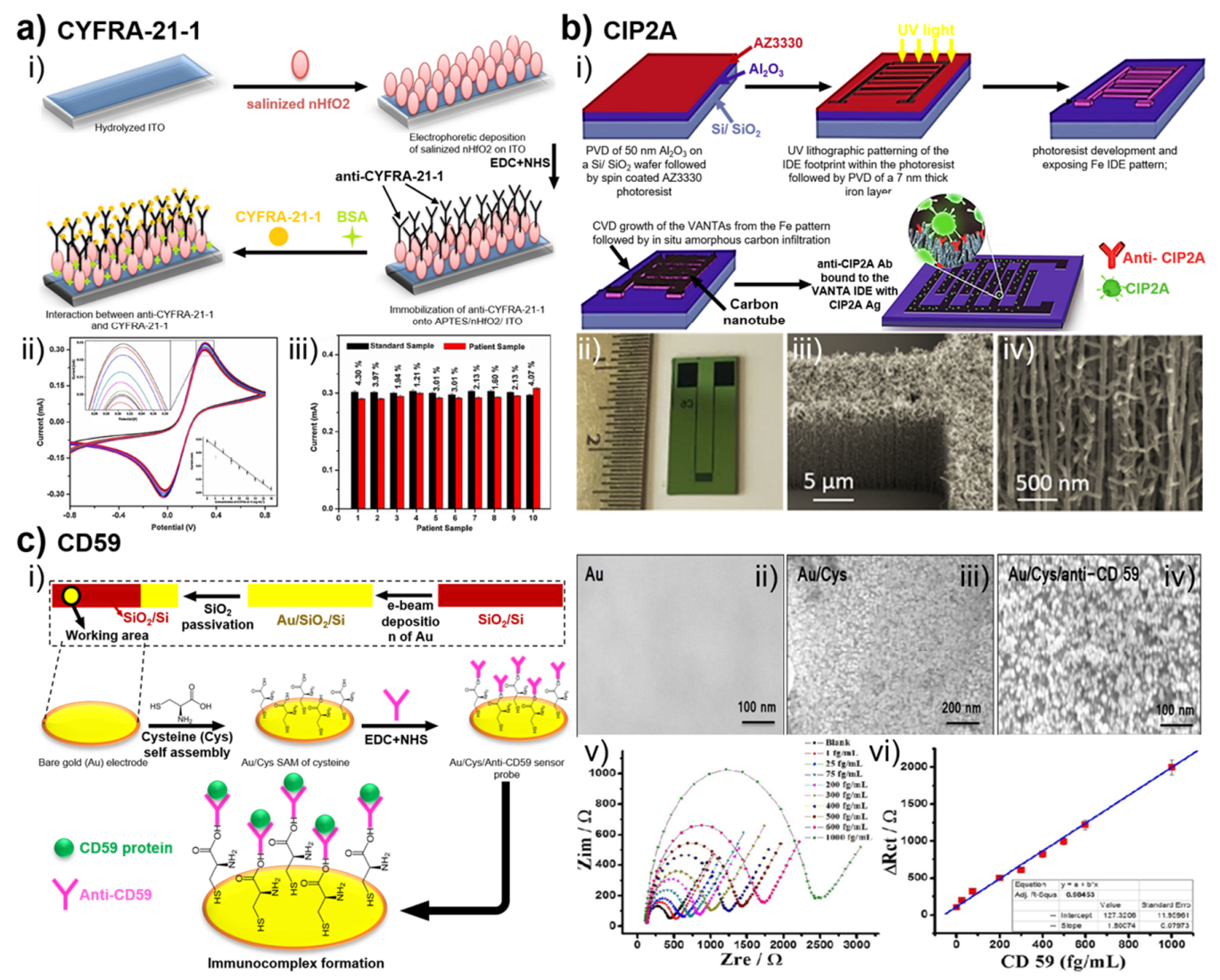

Figure 5. (a) (i) Schematic representation of the fabrication of BSA/anti-CYFRA-21-1/APTES/nHfO $2 / \mathrm{ITO}$ immunosensor for oral cancer detection. (ii) The electrochemical response of modified immunoelectrode in different concentrations of CYFRA-21-1. Insets show the calibration curves of peak current and CYFRA-21-1 concentration. (iii)The comparison between the standard sample and patient samples. (b) (i) Schematic representation of the fabrication steps of VANTA IDEs; (ii) optical image of a VANTA IDE (the values of numbers on the ruler are in centimeters); and (iii, iv) FESEM images of VANTAs from the IDE devices in two magnifications. (c) (i) Schematic representation of the fabrication and the detection principle: (top) the stepwise fabrication of immunosensor; and (below) steps of the fabrication of immunocomplex formation. FESEM images of: bare (ii) Au; (iii) Au/Cys; and (iv) Au/Cys/Anti-CD59 surfaces. (v) EIS responses for CD59 detection in $5 \mathrm{mM}$ zobell's solution and (vi) calibration plot from 1 to $1000 \mathrm{fg} \mathrm{mL}^{-1}$ CD59 concentrations. (a) Adapted with permission from ref. [34]. Copyright 2016 Elsevier. (b) Adapted with permission from ref. [57]. Copyright 2018 Elsevier. (c) Adapted with permission from ref. [48]. Copyright 2014 Elsevier. Abbreviations: 1-Ethyl-3-(3-dimethylaminopropyl)carbodiimide (EDC); N-Hydroxysuccinimide (NHS).

Moreover, Choudhary and coworkers developed a label-free impedimetric immunosensor to diagnose oral cancer by detecting CD59 [48]. The immunosensor probe was fabricated by immobilizing CD59 antibodies (anti-CD59) on a self-assembled molecular layer of L-cysteine (Cys) on a gold electrode. The stepwise of fabrication of the immunosensor is shown in Figure 5c(i). The microphotographs for $\mathrm{Au}, \mathrm{Au} / \mathrm{Cys}$ and Au/Cys/anti- CD59 surfaces are shown in Figure 5c(ii-iv), respectively. CD59 is one of the most fundamental and clinically relevant early-stage markers, that can be used to diagnose oral cancer [44]. Figure 5c(v) shows the EIS response of immunosensor in different concentrations of CD59. The $R_{c t}$ value increased with an increase of CD59 concentrations due to the formation of the insulation layer between CD59 and immunosensor. The immunosensor showed a linear range of detection between 1.0 and $1000 \mathrm{fg} \mathrm{mL}^{-1}$ (Figure 5c(vi)). 


\section{Conclusions}

In this review, DNA biosensor, RNA biosensor and protein biosensor for several salivary biomarkers (such as IL-6, IL-8, TNF- $\alpha$, CYFRA 21-1, CD 59 and CIP2A) have been discussed as promising candidates to provide crucial information for developing non-invasive oral cancer diagnosis. Therefore, the major challenge faced in developing such a diagnostic system accounts for the relatively lower amounts of target analytes present in saliva, which is taken as the diagnostic fluid. However, as the novel and highly sensitive electrochemical biosensor techniques are emerging, the accuracy of analyzing the vital biomarkers in the saliva has been enhanced as well. In addition, these electrochemical sensors meet the requisites, including easy-to-use, non-invasiveness and low cost. The ultrasensitivity and the specificity of biosensors can be improved by combining with MBs, signal probes or nanomaterials on the working electrode so that the electrochemical signal can be more evident. SPdCE and 16-array chips offer the system to detect multiple relevant oral cancer biomarkers simultaneously. However, as oral cancer exhibits some biomarkers that are also corresponding to other types of cancers, their distinctive detection is still an issue. Efforts have been made to differentiate the normal tissues from the different cancerous tissues at various stages by utilizing electrochemical sensing. In the future, the development of electrochemical biosensors on-chip will be one of the main non-invasive detection methodologies of oral cancer at earlier stages in a relatively more precise manner.

Author Contributions: Conceptualization, Y.-T.L., S.D. and T.-E.L.; validation, L.W.; formal analysis, T.-E.L.; investigation, T.-Y.H. and S.-H.L.; resources, H.H.G.; data curation, Y.-T.L. and S.D.; writing-original draft preparation, T.-E.L., Y.-T.L., S.D., A.P. and L.W.; writing-review and editing, T.-E.L., Y.-T.L., S.D., and A.P.; project administration, T.-E.L.; funding acquisition, T.-E.L., S.-H.L., and H.H.G.; All authors have read and agreed to the published version of the manuscript.

Funding: This research was funded by Young Scholar Fellowship Program by Ministry of Science and Technology (MOST) in Taiwan, grant number MOST 108-2636-E-009-012 and 109-2636-B-009-001.

Acknowledgments: Thanks to S.-J. Ji and C.-Y. Chien of the Ministry of Science and Technology (National Taiwan University) for the consulting and data collection.

Conflicts of Interest: The authors declare no conflict of interest.

\section{References}

1. Montero, P.H.; Patel, S.G. Cancer of the oral cavity. Surg. Oncol. Clin. N. Am. 2015, 24, 491-508. [CrossRef] [PubMed]

2. Warnakulasuriya, S. Global epidemiology of oral and oropharyngeal cancer. Oral Oncol. 2009, 45, 309-316. [CrossRef]

3. Chaturvedi, P.; Singh, A.; Chien, C.Y.; Warnakulasuriya, S. Tobacco related oral cancer. BMJ 2019, 365, 12142. [CrossRef]

4. Siegel, R.L.; Miller, K.D.; Goding Sauer, A.; Fedewa, S.A.; Butterly, L.F.; Anderson, J.C.; Cercek, A.; Smith, R.A.; Jemal, A. Colorectal cancer statistics. CA Cancer J. Clin. 2020, 70, 145-164. [CrossRef]

5. Jemal, A.; Siegel, R.; Ward, E.; Hao, Y.; Xu, J.; Murray, T.; Thun, M.J. Cancer statistics. CA Cancer J. Clin. 2008, 58, 71-96. [CrossRef] [PubMed]

6. Messadi, D.V. Diagnostic aids for detection of oral precancerous conditions. Int. J. Oral Sci. 2013, 5, 59-65. [CrossRef] [PubMed]

7. Yen, A.M.F.; Chen, S.C.; Chen, T.H.H. Dose-response relationships of oral habits associated with the risk of oral pre-malignant lesions among men who chew betel quid. Oral Oncol. 2007, 43, 634-638. [CrossRef]

8. Kumar, M.; Nanavati, R.; Modi, T.; Dobariya, C. Oral cancer: Etiology and risk factors: A review. J. Cancer Res. Ther. 2016, 12, 458-463. [CrossRef]

9. Chuang, S.L.; Su, W.W.Y.; Chen, S.L.S.; Yen, A.M.F.; Wang, C.P.; Fann, J.C.Y.; Chiu, S.Y.H.; Lee, Y.C.; Chiu, H.M.; Chang, D.C.; et al. Population-based screening program for reducing oral cancer mortality in 2,334,299 taiwanese cigarette smokers and/or betel quid chewers. Cancer 2017, 123, 1597-1609. [CrossRef]

10. Pearce, A.; Sharp, L.; Hanly, P.; Barchuk, A.; Bray, F.; de Camargo Cancela, M.; Gupta, P.; Meheus, F.; Qiao, Y.L.; Sitas, F.; et al. Productivity losses due to premature mortality from cancer in Brazil, Russia, India, China, and South Africa (BRICS): A population-based comparison. Cancer Epidemiol. 2018, 53, 27-34. [CrossRef] 
11. Gupta, B.; Johnson, N.W.; Kumar, N. Global epidemiology of head and neck cancers: A continuing challenge. Oncology 2016, 91, 13-23. [CrossRef] [PubMed]

12. Srinivas, P.R.; Kramer, B.S.; Srivastava, S. Trends in biomarker research for cancer detection. Lancet Oncol. 2001, 2, 698-704. [CrossRef]

13. Pollaers, K.; Hinton-Bayre, A.; Friedland, P.L.; Farah, C.S. AJCC 8th edition oral cavity squamous cell carcinoma staging-Is it an improvement on the AJCC 7th edition? Oral Oncol. 2018, 82, 23-28. [CrossRef] [PubMed]

14. Mishra, S.; Saadat, D.; Kwon, O.; Lee, Y.; Choi, W.S.; Kim, J.H.; Yeo, W.H. Recent advances in salivary cancer diagnostics enabled by biosensors and bioelectronics. Biosens. Bioelectron. 2016, 81, 181-197. [CrossRef]

15. Chen, X.J.; Zhang, X.Q.; Liu, Q.; Zhang, J.; Zhou, G. Nanotechnology: A promising method for oral cancer detection and diagnosis. J. Nanobiotechnol. 2018, 16, 52. [CrossRef]

16. Hasanzadeh, M.; Shadjou, N.; dela Guardia, M. Non-invasive diagnosis of oral cancer: The role of electro-analytical methods and nanomaterials. TrAC Trends Anal. Chem. 2017, 91, 125-137. [CrossRef]

17. Riedel, F.; Zaiss, I.; Herzog, D.; Götte, K.; Naim, R.; Hörmann, K. Serum levels of interleukin-6 in patients with primary head and neck squamous cell carcinoma. Anticancer Res. 2005, 25, 2761-2766.

18. Ilkhani, H.; Sarparast, M.; Noori, A.; Bathaie, S.Z.; Mousavi, M.F. Electrochemical aptamer/antibody based sandwich immunosensor for the detection of EGFR, a cancer biomarker, using gold nanoparticles as a signaling probe. Biosens. Bioelectron. 2015, 74, 491-497. [CrossRef]

19. Tan, Y.; Wei, X.; Zhao, M.; Qiu, B.; Guo, L.; Lin, Z.; Yang, H.H. Ultraselective homogeneous electrochemical biosensor for DNA species related to oral cancer based on nicking endonuclease assisted target recycling amplification. Anal. Chem. 2015, 87, 9204-9208. [CrossRef]

20. Ma, R.N.; Wang, L.L.; Wang, H.F.S.; Jia, L.P.; Zhang, W.; Shang, L.; Xue, Q.W.; Jia, W.L.; Liu, Q.Y.; Wang, H.F.S. Highly sensitive ratiometric electrochemical DNA biosensor based on homogeneous exonuclease III-assisted target recycling amplification and one-step triggered dual-signal output. Sens. Actuators B Chem. 2018, 269, 173-179. [CrossRef]

21. Chen, J.; Zhang, J.; Guo, Y.; Li, J.; Fu, F.; Yang, H.H.; Chen, G. An ultrasensitive electrochemical biosensor for detection of DNA species related to oral cancer based on nuclease-assisted target recycling and amplification of DNAzyme. Chem. Commun. 2011, 47, 8004-8006. [CrossRef] [PubMed]

22. Wei, F.; Patel, P.; Liao, W.; Chaudhry, K.; Zhang, L.; Arellano-Garcia, M.; Hu, S.; Elashoff, D.; Zhou, H.; Shukla, S.; et al. Electrochemical sensor for multiplex biomarkers detection. Clin. Cancer Res. 2009, 15, 4446-4452. [CrossRef] [PubMed]

23. Aluoch, A.O.; Sadik, O.A.; Bedi, G. Development of an oral biosensor for salivary amylase using a monodispersed silver for signal amplification. Anal. Biochem. 2005, 340, 136-144. [CrossRef] [PubMed]

24. Wei, F.; Liao, W.; Xu, Z.; Yang, Y.; Wong, D.T.; Ho, C.M. Bio/Abiotic interface constructed from nanoscale DNA dendrimer and conducting polymer for ultrasensitive biomolecular diagnosis. Small 2009, 5, 1784-1790. [CrossRef] [PubMed]

25. Malhotra, R.; Patel, V.; Vaqué, J.P.; Gutkind, J.S.; Rusling, J.F. Ultrasensitive electrochemical immunosensor for oral cancer biomarker IL-6 using carbon nanotube forest electrodes and multilabel amplification. Anal. Chem. 2010, 82, 3118-3123. [CrossRef]

26. Saxena, S.; Sankhla, B.; Sundaragiri, K.; Bhargava, A. A review of salivary biomarker: A tool for early oral cancer diagnosis. Adv. Biomed. Res. 2017, 6, 90. [CrossRef]

27. Malon, R.S.P.; Sadir, S.; Balakrishnan, M.; Córcoles, E.P. Saliva-based biosensors: Noninvasive monitoring tool for clinical diagnostics. Biomed Res. Int. 2014, 2014, 962903. [CrossRef]

28. Markopoulos, A.K.; Michailidou, E.Z.; Tzimagiorgis, G. Salivary markers for oral cancer detection. Open Dent. J. 2010, 4, 172-178. [CrossRef]

29. Torrente-Rodríguez, R.M.; Campuzano, S.; Ruiz-Valdepeñas Montiel, V.; Gamella, M.; Pingarrón, J.M. Electrochemical bioplatforms for the simultaneous determination of interleukin (IL)-8 MRNA and IL-8 protein oral cancer biomarkers in raw saliva. Biosens. Bioelectron. 2016, 77, 543-548. [CrossRef]

30. Wang, Z.W.; Zhang, J.; Guo, Y.; Wu, X.Y.; Yang, W.J.; Xu, L.J.; Chen, J.H.; Fu, F.F. A novel electrically magnetic-controllable electrochemical biosensor for the ultra sensitive and specific detection of attomolar level oral cancer-related microRNA. Biosens. Bioelectron. 2013, 45, 108-113. [CrossRef] 
31. Otieno, B.A.; Krause, C.E.; Latus, A.; Chikkaveeraiah, B.V.; Faria, R.C.; Rusling, J.F. On-line protein capture on magnetic beads for ultrasensitive microfluidic immunoassays of cancer biomarkers. Biosens. Bioelectron. 2014, 53, 268-274. [CrossRef] [PubMed]

32. Zhang, Y.; Chen, R.; Xu, L.; Ning, Y.; Xie, S.; Zhang, G.J. Silicon nanowire biosensor for highly sensitive and multiplexed detection of oral squamous cell carcinoma biomarkers in saliva. Anal. Sci. 2015, 31, 73-78. [CrossRef]

33. Kumar, S.; Sharma, J.G.; Maji, S.; Malhotra, B.D. Nanostructured zirconia decorated reduced graphene oxide based efficient biosensing platform for non-invasive oral cancer detection. Biosens. Bioelectron. 2016, 78, 497-504. [CrossRef] [PubMed]

34. Kumar, S.; Kumar, S.; Tiwari, S.; Augustine, S.; Srivastava, S.; Yadav, B.K.; Malhotra, B.D. Highly sensitive protein functionalized nanostructured hafnium oxide based biosensing platform for non-invasive oral cancer detection. Sens. Actuators B Chem. 2016, 235, 1-10. [CrossRef]

35. Qureshi, A.; Gurbuz, Y.; Niazi, J.H. Label-free capacitance based aptasensor platform for the detection of HER2/ErbB2 cancer biomarker in serum. Sens. Actuators B Chem. 2015, 220, 1145-1151. [CrossRef]

36. Lin, T.E.; Chen, W.H.; Shiang, Y.C.; Huang, C.C.; Chang, H.T. Colorimetric detection of platelet-derived growth factors through competitive interactions between proteins and functional gold nanoparticles. Biosens. Bioelectron. 2011, 29, 204-209. [CrossRef] [PubMed]

37. Slamon, D.J.; Godolphin, W.; Jones, L.A.; Holt, J.A.; Wong, S.G.; Keith, D.E.; Levin, W.J.; Stuart, S.G.; Udove, J.; Ullrich, A.; et al. Studies of the HER-2/Neu proto-oncogene in human breast and ovarian cancer. Science 1989, 244, 707-712. [CrossRef]

38. Kumar, L.S.S.; Wang, X.; Hagen, J.; Naik, R.; Papautsky, I.; Heikenfeld, J. Label free nano-aptasensor for interleukin-6 in protein-dilute bio fluids such as sweat. Anal. Methods 2016, 8, 3440-3444. [CrossRef]

39. Tertis, M.; Leva, P.I.; Bogdan, D.; Suciu, M.; Graur, F.; Cristea, C. Impedimetric aptasensor for the label-free and selective detection of interleukin-6 for colorectal cancer screening. Biosens. Bioelectron. 2019, 137, 123-132. [CrossRef]

40. Thomas, J.H.; Kim, S.K.; Hesketh, P.J.; Halsall, H.B.; Heineman, W.R. Microbead-based electrochemical immunoassay with interdigitated array electrodes. Anal. Biochem. 2004, 328, 113-122. [CrossRef]

41. Li, H.; Wei, Q.; He, J.; Li, T.; Zhao, Y.; Cai, Y.; Du, B.; Qian, Z.; Yang, M. Electrochemical immunosensors for cancer biomarker with signal amplification based on ferrocene functionalized iron oxide nanoparticles. Biosens. Bioelectron. 2011, 26, 3590-3595. [CrossRef] [PubMed]

42. Thomas, J.A.; Schnell, F.; Kaveh-Baghbaderani, Y.; Berensmeier, S.; Schwaminger, S.P. Immunomagnetic separation of microorganisms with iron oxide nanoparticles. Chemosensors 2020, 8, 17. [CrossRef]

43. Evtugyn, G.; Hianik, T. Electrochemical immuno- and aptasensors for mycotoxin determination. Chemosensors 2019, 7, 10. [CrossRef]

44. Vasilescu, A.; Fanjul-Bolado, P.; Titoiu, A.M.; Porumb, R.; Epure, P. Progress in electrochemical (bio)sensors for monitoring wine production. Chemosensors 2019, 7, 66. [CrossRef]

45. Shellaiah, M.; Sun, K.W. Review on nanomaterial-based melamine detection. Chemosensors $2019,7,9$. [CrossRef]

46. Zakaria, A.B.M.; Leszczynska, D. Electrochemically prepared unzipped single walled carbon nanotubes-MnO2 nanostructure composites for hydrogen peroxide and glucose sensing. Chemosensors 2019, 7, 1. [CrossRef]

47. Tiwari, S.; Gupta, P.K.; Bagbi, Y.; Sarkar, T.; Solanki, P.R. L-Cysteine capped lanthanum hydroxide nanostructures for non-invasive detection of oral cancer biomarker. Biosens. Bioelectron. 2017, 89, 1042-1052. [CrossRef]

48. Choudhary, M.; Yadav, P.; Singh, A.; Kaur, S.; Ramirez-Vick, J.; Chandra, P.; Arora, K.; Singh, S.P. CD 59 targeted ultrasensitive electrochemical immunosensor for fast and noninvasive diagnosis of oral cancer. Electroanalysis 2016, 28, 2565-2574. [CrossRef]

49. Verma, S.; Singh, A.; Shukla, A.; Kaswan, J.; Arora, K.; Ramirez-Vick, J.; Singh, P.; Singh, S.P. Anti-IL8/AuNPs-RGO/ITO as an immunosensing platform for noninvasive electrochemical detection of oral Cancer. ACS Appl. Mater. Interfaces 2017, 9, 27462-27474. [CrossRef] [PubMed]

50. Khanmohammadi, A.; Aghaie, A.; Vahedi, E.; Qazvini, A.; Ghanei, M.; Afkhami, A.; Hajian, A.; Bagheri, H. Electrochemical biosensors for the detection of lung cancer biomarkers: A review. Talanta 2020, 206, 120251. [CrossRef] 
51. Darvishi, S.; Pick, H.; Lin, T.E.; Zhu, Y.; Li, X.; Ho, P.C.; Girault, H.H.; Lesch, A. Tape-stripping electrochemical detection of melanoma. Anal. Chem. 2019, 91, 12900-12908. [CrossRef] [PubMed]

52. Lin, T.-E.; Lu, Y.-J.; Sun, C.-L.; Pick, H.; Chen, J.-P.; Lesch, A.; Girault, H.H. Soft electrochemical probes for mapping the distribution of biomarkers and injected nanomaterials in animal and human tissues. Angew. Chem. Int. Ed. 2017, 56, 16498-16502. [CrossRef] [PubMed]

53. Lin, T.E.; Bondarenko, A.; Lesch, A.; Pick, H.; Cortés-Salazar, F.; Girault, H.H. Monitoring tyrosinase expression in non-metastatic and metastatic melanoma tissues by scanning electrochemical microscopy. Angew. Chem. Int. Ed. 2016, 55, 3813-3816. [CrossRef] [PubMed]

54. Pachauri, N.; Dave, K.; Dinda, A.; Solanki, P.R. Cubic CeO2 implanted reduced graphene oxide-based highly sensitive biosensor for non-invasive oral cancer biomarker detection. J. Mater. Chem. B 2018, 6, 3000-3012. [CrossRef]

55. Hasanzadeh, M.; Shadjou, N.; dela Guardia, M. Early stage screening of breast cancer using electrochemical biomarker detection. TrAC Trends Anal. Chem. 2017, 91, 67-76. [CrossRef]

56. Singh, S.; Gill, A.A.S.; Nlooto, M.; Karpoormath, R. Prostate cancer biomarkers detection using nanoparticles based electrochemical biosensors. Biosens. Bioelectron. 2019, 137, 213-221. [CrossRef]

57. Ding, S.; Das, S.R.; Brownlee, B.J.; Parate, K.; Davis, T.M.; Stromberg, L.R.; Chan, E.K.L.; Katz, J.; Iverson, B.D.; Claussen, J.C. CIP2A immunosensor comprised of vertically-aligned carbon nanotube interdigitated electrodes towards point-of-care oral cancer screening. Biosens. Bioelectron. 2018, 117, 68-74. [CrossRef]

58. Aydın, M.; Aydın, E.B.; Sezgintürk, M.K. A highly selective electrochemical immunosensor based on conductive carbon black and star PGMA polymer composite material for IL-8 biomarker detection in human serum and saliva. Biosens. Bioelectron. 2018, 117, 720-728. [CrossRef]

59. Verma, S.; Singh, S.P. Non-invasive oral cancer detection from saliva using Zinc oxide-reduced graphene oxide nanocomposite based bioelectrode. MRS Commun. 2019, 9, 1227-1234. [CrossRef]

60. Deckert, F.; Legay, F. Development and validation of an IL-6 immuno-receptor assay based on surface plasmon resonance. J. Pharm. Biomed. Anal. 2000, 23, 403-411. [CrossRef]

61. Malhotra, R.; Urs, A.B.; Chakravarti, A.; Kumar, S.; Gupta, V.K.; Mahajan, B. Correlation of cyfra 21-1 Levels in saliva and serum with CK19 MRNA expression in oral squamous cell carcinoma. Tumor Biol. 2016, 37, 9263-9271. [CrossRef] [PubMed]

62. Alevizos, I.; Mahadevappa, M.; Zhang, X.; Ohyama, H.; Kohno, Y.; Posner, M.; Gallagher, G.T.; Varvares, M.; Cohen, D.; Kim, D.; et al. Oral cancer in vivo gene expression profiling assisted by laser capture microdissection and microarray analysis. Oncogene 2001, 20, 6196-6204. [CrossRef] [PubMed]

63. Babiuch, K.; Kuśnierz-Cabala, B.; Kęsek, B.; Okoń, K.; Darczuk, D.; Chomyszyn-Gajewska, M. Evaluation of proinflammatory, NF-KappaB dependent cytokines: IL- $1 \alpha$, IL-6, IL-8, and TNF- $\alpha$ in tissue specimens and saliva of patients with oral squamous cell carcinoma and oral potentially malignant disorders. J. Clin. Med. 2020, 9, 867. [CrossRef] [PubMed]

64. Sahibzada, H.A.; Khurshid, Z.; Khan, R.S.; Naseem, M.; Siddique, K.M.; Mali, M.; Zafar, M.S. Salivary IL-8, IL-6 and TNF- $\alpha$ as potential diagnostic biomarkers for oral cancer. Diagnostics 2017, 7, 21. [CrossRef]

65. Chen, Z.; Malhotra, P.S.; Thomas, G.R.; Ondrey, F.G.; Duffey, D.C.; Smith, C.W.; Enamorado, I.; Yeh, N.T.; Kroog, G.S.; Rudy, S.; et al. Expression of proinflammatory and proangiogenic cytokines in patients with head and neck cancer. Clin. Cancer Res. 1999, 5, 1369-1379. [PubMed]

66. Tanaka, T.; Narazaki, M.; Kishimoto, T. Il-6 in inflammation, immunity, and disease. Cold Spring Harb. Perspect. Biol. 2014, 6, a016295. [CrossRef]

67. Gokhale, A.S.; Haddad, R.I.; Cavacini, L.A.; Wirth, L.; Weeks, L.; Hallar, M.; Faucher, J.; Posner, M.R. Serum concentrations of interleukin-8, vascular endothelial growth factor, and epidermal growth factor receptor in patients with squamous cell cancer of the head and neck. Oral Oncol. 2005, 41, 70-76. [CrossRef]

68. Chen, X.; Jia, X.; Han, J.; Ma, J.; Ma, Z. Electrochemical immunosensor for simultaneous detection of multiplex cancer biomarkers based on graphene nanocomposites. Biosens. Bioelectron. 2013, 50, 356-361. [CrossRef]

69. Wei, Q.; Mao, K.; Wu, D.; Dai, Y.; Yang, J.; Du, B.; Yang, M.; Li, H. A novel label-free electrochemical immunosensor based on graphene and thionine nanocomposite. Sens. Actuators B Chem. 2010, 149, 314-318. [CrossRef]

70. Darvishi, S.; Souissi, M.; Kharaziha, M.; Karimzadeh, F.; Sahara, R.; Ahadian, S. Gelatin methacryloyl hydrogel for glucose biosensing using ni nanoparticles-reduced graphene oxide: An experimental and modeling study. Electrochim. Acta 2018, 261, 275-283. [CrossRef] 
71. Darvishi, S.; Souissi, M.; Karimzadeh, F.; Kharaziha, M.; Sahara, R.; Ahadian, S. Ni nanoparticle-decorated reduced graphene oxide for non-enzymatic glucose sensing: An experimental and modeling study. Electrochim. Acta 2017, 240, 388-398. [CrossRef]

72. Kuila, T.; Bose, S.; Khanra, P.; Mishra, A.K.; Kim, N.H.; Lee, J.H. Recent advances in graphene-based biosensors. Biosens. Bioelectron. 2011, 26, 4637-4648. [CrossRef] [PubMed]

73. Zhong, L.P.; Zhu, H.G.; Zhang, C.P.; Chen, W.T.; Zhang, Z.Y. Detection of serum cyfra 21-1 in patients with primary oral squamous cell carcinoma. Int. J. Oral Maxillofac. Surg. 2007, 36, 230-234. [CrossRef] [PubMed]

74. Fowler, J.D.; Allen, M.J.; Tung, V.C.; Yang, Y.; Kaner, R.B.; Weiller, B.H. Practical chemical sensors from chemically derived graphene. ACS Nano 2009, 3, 301-306. [CrossRef] [PubMed]

75. Li, X.; Batchelor-McAuley, C.; Shao, L.; Sokolov, S.V.; Young, N.P.; Compton, R.G. Quantifying single-carbon nanotube-electrode contact via the nanoimpact method. J. Phys. Chem. Lett. 2017, 8, 507-511. [CrossRef]

76. Böckelman, C.; Hagström, J.; Mäkinen, L.K.; Keski-Säntti, H.; Häyry, V.; Lundin, J.; Atula, T.; Ristimäki, A.; Haglund, C. High CIP2A immunoreactivity is an independent prognostic indicator in early-stage tongue cancer. Br. J. Cancer 2011, 104, 1890-1895. [CrossRef]

(C) 2020 by the authors. Licensee MDPI, Basel, Switzerland. This article is an open access article distributed under the terms and conditions of the Creative Commons Attribution (CC BY) license (http://creativecommons.org/licenses/by/4.0/). 